\title{
Between Law and Traditions: the Practice of (Non) Participation of Girls from the Albanian Community in Macedonia in the Family Property Inheritance
}

Lindita Neziri, MA

Southeast European University, Tetovo

Abdulla Azizi, PhD

Southeast European University, Tetovo

\begin{abstract}
In the Republic of Macedonia after the state independence (1991) property issues, we have arranged through legal norms, but there are many factors that hamper the correct implementation of the goal set out in the positive norms for property inheritance.In the literature so far, we can find information and analysis of the law, the legal and institutional heritage system, litigation cases, comparative aspects of legal norms, but there is a lack of scientific research on the reasons for the low rate of girls' involvement in the legal part of the family property inheritance which belongs to them. Within this paper, we have analyzed the practical circumstances in Macedonia from the context of girls (non) inclusion in the family property inheritance, or more precisely "voluntary" resignation from inheritance. Rather, in focus of the analysis are the circumstances that affect their resignation.In order to reach the primary data, we realized an empirical study, i.e. a questionnaire survey, including girls (female heirs) from the Albanian community in Macedonia, which have completed the inheritance process on family property within legitimate institutions. Finally, we analyze the data and draw conclusions. Also, suggestions are given to serve the broad academic community, policy-makers, and stakeholders, who may raise issues as a problem that requires special institutional and educational treatment.
\end{abstract}

Keywords: property inheritance, non-inclusion of girls, Macedonia

\section{Introduction}

Guaranteeing the hereditary rights of girls is increasingly growing through a number of legal acts at the national and international level to respect the principle of gender equality. However, their implementation in practice, unfortunately, remains at the mercy of traditional attitudes to society.

Today, guaranteeing the hereditary rights of female heirs in transition countries remains an issue that needs to be devoted attention.

Systems and property rights vary from one society to another, depending on cultural, political and legal factors. Exclusion of women from property puts them in a disadvantageous, unseen and dependent position on men. Generally speaking, denial of inheritance rights definitely affects the economic security and independence of women in society, which is in contrary to contemporary international trends that empower the role of women in the family.

However, patriarchal family organization, from generation to generation, excludes girls from inheritance rights. Also, Albanian girls in Macedonia are still being excluded from family property inheritance, and this is a long-standing challenge that requires more appropriate legal, institutional and educational solutions.

There is an impression that the tendency towards circumventing laws continues because lawmakers have not foreseen all the possible circumstances of misuse, taking into account the tradition as well. This has nothing to do with unlawful actions, but for lack of norms that would hinder a tradition that is contrary to the aim of the law. Moreover, since legal norms should serve the citizens to the practical implementation of the law, and at the same time, it is required to foresee mechanisms for avoiding possible misuse. 
Research has provided enough evidence to prove that girls in the inheritance process of family property are victims of culture and tradition which excludes them from their legal right.

The research is structured in two parts. The first part of paper deals with the legal framework; the gap between law and tradition; and good international practices during the inheritance process. The second part analyzes the data onto field research that shows the reality and beliefs of the focus group on issues of family property inheritance.

The study ends with conclusions and recommendations, which aim to outline how to overcome, identified problems or improve the processes of recognizing female inheritance rights.

\section{Purpose of the research}

The overall purpose of the research is to look at the reasons that prevent Albanian girls in Macedonia from enjoying hereditary rights and at the same time to contribute theoretically to the provision of data that could serve the wider community.

Examination of the reasons will be made through analysis of legal, procedural and administrative deficiencies that are restricting female heirs from property inheritance and identifying traditional barriers that hinder the participation of female heirs in inheritance.

The study also has other purposes related to the main purpose: proper information on the real situation regarding inheritance practices; raising female heirs awareness of their inheritance rights and procedures to be followed; promoting legal and procedural reforms in accordance with best international practices that can contribute to gender equality in inheritance; improving access to the treatment of inheritance issues by the competent bodies.

\section{Material and method of work}

For the proper study of the situation regarding the hereditary rights of Albanian female heirs in Macedonia, methods of theoretical, empirical and comparative analysis have been used. At first, a qualitative analysis of the impact of legal provisions on hereditary relationships has been made. Subsequently, comparative methods were used, due to their impact on the practical implementation of customary norms and legal norms.

Materials from the literature and field research materials have been used. Literature has been reviewed in order to analyze tradition, legislation, and practice referring to the inheritance of family property by Albanian daughters in Macedonia. The method of analysis has been focused on normative acts, research findings and conclusions drawn.

The survey included the implementation of a questionnaire, dedicated to randomly selected respondents. Direct meetings were held with respondents to give their answers, and additional discussions were held regarding the clarification of the opinion on their inheritance experiences. The data obtained were processed according to simple quantitative and qualitative methods of analysis.

\section{Literature overview}

According to the statistical data from the last census of 2002 in the Republic of Macedonia live 2,022,547 of which over $509,083(25.17 \%)$ are citizens of the Albanian community (SSO, 2002:20). The majority of the Albanian population is located in the western part of the country, namely the Polog region, where it is evident the parallel functioning of social and legal norms, in terms of inheritance (Memeti, 2017:4). Here, it is interesting to note that women, according to Islam, have inheritance rights (Roald, 2001), while the Kanun advocates the opposite (Boman and Krasniqi, 2012:11)

The Kanun is a set of traditional Albanian laws, developed by Lekë Dukagjini and composed of 12 books and 1,263 articles. The Kanun was codified in the 15th century and it has been used mostly in northern and central Albania and surrounding areas formerly in Yugoslavia, where there is a large ethnic Albanian population; Montenegro, Kosovo, and Macedonia. The influence of tradition on inheritance issues is described in the marriage section of the Kanun, where only the sons are recognized as heirs and not the daughters. The rules of inheritance have been defined in Chapter 8 , "A wife doesn't receive a share of inheritance either from her parents or from her husband". The reasons for this are the following: "a) To prevent her sons from settling in the home of her uncle who has no heirs; b) To prevent the woman's parents from settling in the home of her husband who leaves no heirs; c) To prevent the clan of one Banner from mixing with the clan of another Banner". 
By tradition, real estate is held on behalf of the older son, because the family land has been kept for generations and shouldn't be transferred to others after the father's death. It is a tradition practiced in families with more descendants, to live together in a large family house, where each of the brothers gets a part of the home for the family themselves. In cities, this traditional pattern of life rarely happens, though can be found a half-split homes, brothers' homes, or multi-family dwellings (Joireman, 2015: 234-50).

Real estate, particularly house and family land, is transmitted to the male line. A briefing issued to the Human Rights Committee in 2007 notes that "property is usually left solely to male heirs" (Frishchik \& Duarte, 2007:4).

It has strong resistance to transferring property to female heirs and transferring it outside the family of origin. If female heirs seeking family property inheritance, they often face considerable obstacles, as they are thought to embarrass their family, and hurt family relationships, especially with their brothers. Many women choose to give up their property rights because of these social norms (USAID, 2016:162).

The patriarchal model is said to have been particularly intensive in traditional village communities, but certain authors find this model as still very alive and present in the contemporary Balkan context (Kaser, 2008).

It is thought that if the daughter obtains a part of the real estate than she enriches another family and not hers (Mircevska, 2008:476). Only sons can enrich their families through people and property; they are the representatives of the clan, and it is thereupon that all land and livestock remain with them (Erlich, 1964). The traditional environment, as no other, shows resistance to any modern legal regulations, which are unfamiliar and distant and do not consider the current stage of societal development and family relations, although the influence of tradition over all spheres of human life has fallen over recent decades (Mircevska, 2008:478).

When it comes to the status of the woman in the family in the Macedonian traditional culture, states that "inside the family structure on an existential level, the position of the female heirs wasn't as unfavorable as we can sometimes read it was. Practically, there are only very few examples of families where inside the family relations, the male group has significantly more important place than the female one" (Svetieva, 2002:115-124). In another study in this area, including the citizens of the Macedonian community, tradition has affected only $25 \%$ in the decision on inheritance; the decision for inheritance has been shared by all the $88 \%$ inheritors; while hereditary girls and boys maintain that they have the equal right to the inheritance of the parental property 93\% (Mitrevska, 2017:26).

The term "patriarchal" is not fair to describe the status of women in the contemporary context, so some authors oppose its widespread use (Risteski, 2002: 91-115; Cvetanovska, 2014: 121-140).

By empowering women's position in the private and public sphere, the necessary conditions for changing the deeply entrenched patriarchal consciousness are acquired, thus establishing strategies for gender equality as a necessary condition for the modern developmental processes" (Stjepanović-Zaharijevski, 2006:233-243).

Today, there is a potential to question the thesis of re-establishing traditionalism in the context of the status of female heirs. According to this interpretation, the "woman" does not necessarily have to be treated as humble, dominated, trivial, etc. (Gajtanoska, 2017:614).

\section{The legal framework}

The hereditary right in Macedonia should be analyzed through the following acts: Family Law (2014), Law of Property and Other Real Rights (2001), Law of Inheritance (1996) and Law on Equal Opportunities between Men and Women (2006).

The Law on Inheritance explicitly stipulates that men and women have the same rights to inheritance (CEDAW, 2004:13). Article 3 specifies that "citizens are equal to inheritance". However, it is possible to exclude the descendants in inheritance proceedings under special conditions (Article 46) and to resign their inheritance (Articles 128-131), which creates opportunities for misuse to the detriment of the interests of female heirs. This legal definition contradicts the tradition of continental Europe, where most of the property is reserved for children and must necessarily be equally divided between them (Vangjeli, 2010:55-77).

The inheritance process in Macedonia has been regulated through some legal rules. Law on Notary (2007) freed the Courts from the workload and opened the possibility for citizens to realize their rights, especially those related to inheritance, while 
with amendments to the 2008 Law on Obligations and the 2008 Nonlitigation Procedure Law, notaries gained greater powers over inheritance and ownership. Based on the Law on Obligations, notaries have acquired the right to draft a lifelong contract and the transfer of property during their lifetime, which was previously under the jurisdiction of the Court. In addition, notaries have acquired the right to draft such contracts as a notarial act (Article 4). Upon approval of the Nonlitigation Procedure Law, notaries became trustees of the court and gained competencies regarding the treatment of inheritance (Articles 131-141).

Like any other legal issue, as well as the property inheritance, it requires knowledge of the law, the judicial-notary process, and its implementation. As far as knowledge is concerned, girls do not always know that they have the legal right to inherit from their parents. The fact that feminine legacy is unknown in their tradition does not encourage the titular to read the law. As far as the second obstacle is concerned - the lack of knowledge of the judicial and notary process, from the moment of the death of the parent from which the property is inherited, until a decision on the division of property is required, a personal commitment to participation in the inheritance process is required, which is also related to statements and sometimes even disputes that may also lead to court proceedings. The third legal obstacle-enforcement of the decision and the transfer of inherited property, the payment of the notarial fees related to the transfer of ownership, then the registration in Cadastre etc., is also an additional commitment requiring dedication, time and financial expenses.

\section{The gap between law and practice in Macedonia seen by the international community}

An impression was expressed that the process of democratization in Macedonia didn't lead to the implementation of the laws in practice and that it has a significant difference in laws and practice. Moreover, reports and research conducted by international institutions confirm the gap between law and practice.

At world level, in the framework of the study conducted by the OECD Development Centre's Social Institutions and Gender Index (SIGI), as a cross-country measure of discrimination against women in social institutions (formal and informal laws, social norms, and practices) across 160 countries, only in 55 states women are guaranteed the same inheritance rights as men, both in law and in practice (OECD, 2014:6). The study highlights countries with very low levels of gender discrimination in social institutions, which are characterized by strong legal frameworks and measures ensuring gender equality, where women and men have equal rights and heritage (Argentina, Belarus, Belgium, Czech Republic, France, Italy, Serbia, Slovenia, Spain, etc.). Meanwhile, Macedonia falls into the group of countries with a high level of gender discrimination in social institutions, characterized by inconsistent legal frameworks covering family code, inheritance, and access to women in resources; the strong influence of customary practices and parental authority (OECD, 2014:7).

Particularly in the annual reports of the European Commission on Macedonia's Progress, the European Commission underlines:

"Notwithstanding some progress towards gender equality for women from ethnic minorities, discriminatory customs and traditions, along with stereotypes, remain very present" (Report, 2008:52);

"The practice of family voting, along with other discriminatory customs, traditions and stereotypes, are still widespread and undermines women's basic rights" (Report, 2009:18); Support for activities and initiatives aimed at combating discriminatory customs and traditions and stereotypes remains insufficient (Report, 2009:54; Report, 2010:54; Report, 2011:54, Report, 2012:47);

"Discriminatory customs, traditions and stereotypes are widespread and undermine women's basic rights" (Report, 2010:18, Report, 2011:18, Report, 2012:15);

"Discriminatory customs, traditions and stereotypes remain significant, capitalizing on underlying regressive trends in society" (Conclusions, 2013:37); "Discriminatory customs, traditions and stereotypes remain significant and are open to exploitation and the fostering of regressive trends in society" (Conclusions, 2013:44);

"Gender stereotyping persists and further measures are needed to combat double or multiple discrimination, particularly against Roma women" (Report, 2015:59);

"Public awareness of gender equality is lacking and gender stereotyping persists" (Report, 2016:61)

\section{Best international practices in the inheritance process: the notary's role}


Some European countries, in their legal system, have the most appropriate and proven solutions in practice that can improve the inheritance process in Macedonia as well. Below we will briefly review those legal provisions, which relate to inheritance contract, notarial contract, the Register of Wills and the principle of universal inheritance.

One of the basics of an inheritance, in addition to will and law is the Heritage Contract, which has priority to the application before the Will and law. The inheritance contract is defined as "a legal act by which the contracting parties regulate inheritance to themselves or for the benefit of a third party" (Pravni leksikon, 1964:967). The inheritance contract differs from the contract for lifelong support for two main characteristics: the decedent doesn't have the inheritance share, which is legally guaranteed to the heirs, and the heirs inherit the rights and obligations of the decedent.

In comparative terms, the inheritance contract is foreseen in Germany (Section $1941 \mathrm{BGB}$ ), Austria (§602 ABGB Erbverträge), Switzerland (Article 468 Civil Code), Spain (Art.658 and 892 Civil Code), Czech Republic (Section 1582-1593 Civil Code) and in other countries. Comparative laws foresee different solutions for contracting parties to the Heritage Contract. According to German and Swiss law, the inheritance contract can be concluded between each person. Otherwise, according to French law, the property gift agreement in the future may be related only to the spouse (Code Civil, Article 1091-1099), and may only be made to the benefit of their offspring. Even the Austrian Civil Code allows the signing of a Heritage Contract only between spouses ( $\$ 602$ and $\$ 1249$ ABGB).

In its form, the Heritage Contract is a formal act. According to the German and Swiss law (Article 512 Swiss Civil Code), it can only be made in the form of a public document by the notary in the simultaneous presence of both parties, according to the rules for the compilation of a Public Will. However, in practice, the Heritage Contract is drafted by the notary in the form of a public document to be confirmed by another notary or two witnesses (Eccher, 2002: 71; Stojanović, 2003:165).

The Subject of the Heritage Contract is the whole inheritance or part of the inherited property. However, the freedom to make the Heritage Contract is legally limited to the indispensable part (Article 2303 German BGB, Articles 912-917 French Civil Code). In the case of a breach of the necessary part, the heirs may apply for a reduction of the Heritage Contract.

Another good international practice is the Notary Testament. There are often situations where neither the heirs nor the notary who carries out the hereditary procedure knows that there is a will; therefore the inheritance is divided according to the Law on Inheritance. If, after the Decision of the inheritance, a later will be found a testament, then another decision should be taken to revoke the Inheritance sharing Decision. Also, there are cases when one of the heirs knows the content of the Will, so it does not show it. As a result of these circumstances, due to the lack of legal norms for evidencing the Wills, a violation of the principle of legal certainty may occur, and this puts into question the will of the decedent.

In Macedonia, the existence of the notary's will is not foreseen as a special type of testimony within the Inheritance Law. According to Article 58 of the Law on Notary, notaries may draft testaments in the form of a notarial act, according to the provisions that fall to make a judicial testament. Unlike Macedonia, the notarial testament is recognized in comparative law (Ristov, 2012: 70-82). The notary testament is envisaged in the countries of the region: in the Montenegrin legislation (Article 69 of the Law on Heritage), Croatia (article 32 of the Law on Heritage) and the Republika Srpska (article 72 of the Law on Heritage).

There are different models of Notary Testament: without the presence of witnesses (Germany, the Netherlands, Spain, Russia, Poland, Serbia); with the presence of two witnesses (Bulgaria, Italy, Turkey, Czech Republic), with three witnesses (Greece); or instead of witnesses, the participation of another notary -Belgium and France.

Also, in comparative law, there are laws that regulate the Testament Registry as a system that enables the heirs and competent authorities to be aware that the deceased has left a Will and where it is located. According to the provisions of the Dutch Civil Code, the notary is obliged to notify the Central Register of Wills that he has prepared a testament or has been submitted to him to hold it (Garb, 2004:435). These testaments remain to be kept by a notary, while extraordinary Wills are sent to the Central Registry of Wills (Title 4 Dutch Civil Code). After the death of a person, the notary is obliged to look at the Central Registry if the testator has drafted a Will. Similarly, the Czech Notary Chamber is responsible for administering the Central Registry of Wills (division 2, Czech Republic Civil Code), which presents a list of public Wills and those deposited by notaries. The notary who compiles a testament is obliged to notify the Central Registry.

This reform process has also begun in the countries of the region. Croatia's Law of Inheritance (2003) has foreseen the Testament Register, which is administered by the Notary Chamber (article 68). The registration of testament data is done 
on a voluntary basis and has a declarative character (Klarić \& Vedriš: 2006:751). Following the Croatian example, Montenegro also made changes to the Law on Inheritance (2008), envisioning the Testament Register, as a public document kept by the Notary Chamber in accordance with the Regulations of the Ministry of Justice. The data on the Registry of Wills, upon the request of the decedent, must be submitted by the competent courts, notaries, lawyers, and persons who have made a testament. Data cannot be made available to anyone before the decedent's death, except for the person he has specifically authorized for this purpose.

As a safeguard to guarantee inheritance rights, Germany has laid down the Principle of Universal Succession (Section 1922 German Civil Code), where all heirs legally inherit the property of the deceased person at the time of death without the need for legal proceedings. Heirs who want to give up their inheritance can do so within 6 weeks after the death of the decedent, respectively 6 months if they live abroad (Section 1944 German Civil Code). Each heir should be given full information on the value of the property he is giving up as well as his claims on the inheritance. Heirs then have the opportunity to jointly agree on the division of property or the sale of their share where co-heirs have the right of priority for the purchase.

\section{Results from the research}

The questionnaire used in this research is composed of 17 questions. It is designed to include data on the demographic and socio-economic status of respondents, as well as responses to their perceptions of hereditary rights. It is worth mentioning that research involves only female gender, and is limited to Albanian female heirs in Macedonia.

Field research was conducted on the basis of a questionnaire consisting of general questions about the situation regarding inheritance and female heirs attitudes about property inheritance, questions that try to obtain data from female heirs what their attitudes are about property inheritance, in general, focusing more on determining the system of values in society in terms of property inheritance.

In this survey, 508 female heirs over the age of 18 were included. Within the Questionnaire there are seven questions related to the following variables:

1. Residence - Village (50\%), City $(50 \%)$;

2. Age - $18-30(6 \%), 31-40(31 \%), 41-50(35 \%)$, over $51(30 \%)$;

3. Marital status - Married (70\%), Unmarried (16\%), Divorced (4\%), Widower (10\%);

4. Education - Uneducated (2\%), with elementary school (32\%), High school $(52 \%)$, with faculty and more $(14 \%)$;

5. Employment status - Unemployed (76\%), Employed (24\%);

6. Net monthly household income in € - Up to 150 (18\%), 150-250 (21\%), 250-350 (22\%), 350-450 (24\%), 450-550

(12\%), over $550(3 \%)$;

7. Number of members in the family - One (2\%), Two (9\%), Three (31\%), Four (40\%), Five (18\%), Six and more (2\%).

While ten other questions have to do with respondents' perceptions of the issues that are a matter of research

\begin{tabular}{|c|c|c|c|}
\hline Questions/Answers & Yes & No & $\begin{array}{l}\text { I have no } \\
\text { answer }\end{array}$ \\
\hline $\begin{array}{l}\text { Do you know about your legal right and the procedures to be followed in the inheritance of } \\
\text { parental property? }\end{array}$ & $52 \%$ & $39 \%$ & $9 \%$ \\
\hline \multicolumn{4}{|c|}{$\begin{array}{l}\text { A significant proportion of female heirs (52\%) have knowledge of their right to inheritance (although they do not know the inheritance } \\
\text { procedure in the competent institutions); another part (39\%) has no knowledge of the laws and procedures to be followed in realizing } \\
\text { the right to inherit; while a smaller part considers that they have no interest in recognizing inheritance laws and procedures }(9 \%) \text {. }\end{array}$} \\
\hline Have you requested within your family the legal title of your inheritance? & $32 \%$ & $62 \%$ & $6 \%$ \\
\hline \multicolumn{4}{|c|}{$\begin{array}{l}\text { The female heirs seem to be influenced by the tradition in their attitudes regarding the requirement to be part of the family heritage. } \\
\text { Most }(62 \%) \text { did not request parents to participate in the inheritance. Only } 32 \% \text { have shown interest in participating in the inheritance } \\
\text { of parental property, while } 6 \% \text { are still unspecified. The reasons for this inactivity can be found in the female heirs conviction that } \\
\text { "they will be judged by the family and the society," and the great concern for maintaining relationships with parents and brothers. }\end{array}$} \\
\hline Have you inherited a portion of the property of your parents, legally entitled to you? & $25 \%$ & $69 \%$ & $6 \%$ \\
\hline \multicolumn{4}{|c|}{$\begin{array}{l}\text { Every } 1 / 4 \text { of the female heirs have received a share of their inheritance, and this has mainly resulted from } \\
\text { (divorce, poor financial condition, husband's pressure, etc.) as the financial solidarity from her family to th } \\
\text { Most (69\%) did not inherit property from their parents, while a small part }(6 \%) \text { did not answer this questic } \\
\text { had not yet been completed (mainly girls of younger age). Female heirs excluded from inheritance consi }\end{array}$} \\
\hline
\end{tabular}


part of the inheritance should be given to the daughters.

Do you have an understanding with your parents about the inheritance of the property in your part?

There is a belief in most respondents (77\%) that there is no understanding of the male part of the family about the issue of female heirs' inheritance since women are still considered to be dependent on men and the transfer of property to a daughter implies transferring property to the groom. Only $1 / 5$ of the female heirs consider that the discussion about inheritance within the family does not present any disadvantages in family relations and that there is understanding between the inheritors. While only $3 \%$ do not find it reasonable to answer this question.

\begin{tabular}{l}
$\begin{array}{l}\text { If you have inherited property from the parents, are you treated as an heir equal to the } \\
\text { brothers? }\end{array}$ \\
\hline
\end{tabular}

We cannot yet speak about gender equality in heritage issues. In fact, the majority of the respondents (83\%) considers that they are not treated equally in the inheritance process, despite a minority $(9 \%)$ who has the inheritance equality experience, while $8 \%$ did not have an answer.

\begin{tabular}{|l|l|l|l}
\hline Has the tradition played a role in your resignation from property inheritance? & $85 \%$ & $11 \%$ & $4 \%$
\end{tabular}

In the inheritance process, tradition has a key role. Thus, there is considerable conviction among the respondents (85\%) that tradition plays a decisive role in the division of family property between male and female heirs. This is related to the "obligation" for allegedly rendering a voluntary declaration of resignation from property inheritance. Only a few surveyed $(11 \%)$ consider that their families have overcome barriers of tradition, while $4 \%$ have no answer.

Do you think that the mentality and patriarchal traditions that have to do with the inheritance of property need to be changed in the future?

Patriarchal mentality and patrimonial tradition of property inheritance are considered to be changed $(72 \%)$ while there is still a small and conservative number $(15 \%)$ of women who are convinced that the tradition should be maintained, while $13 \%$ have not responded.

Did your participation in the inheritance of family property have adversely affected the relationship with the parents/brothers?

Female heirs' requests to participate in the property's inheritance have a significant adverse impact on relationships with family males $(73 \%)$. Every $1 / 4$ of the female heirs are convinced that their inheritance demand has not dampened their relationship with the family, while $2 \%$ have no answer.

\begin{tabular}{l}
$\begin{array}{l}\text { In the circumstances of more advanced gender equality in society, would you seek to be } \\
\text { equal in the inheritance of parental property? }\end{array}$ \\
\hline
\end{tabular}

Respondents almost agree (89\%) that in normal circumstances when both parents and brothers would understand the inheritance issue fairly, within a society where gender equality would have been previously achieved, then it would be possible to talk about equality of inheritance of property. Only a few respondents (3\%) think that they will not seek property inheritance from parents, while $8 \%$ have no answer.

\begin{tabular}{|l|l|l|l|}
\hline In a process of inheritance of your property, would you have divided it into equal shares for & $38 \%$ & $52 \%$ & $10 \%$
\end{tabular} boys and girls alike?

Finally, respondents were placed in the role of a parent who would divide the property among his own children. Thus, a considerable part $(38 \%)$ has the conviction to change the tradition in favor of daughter heirs, increasing their share in the inheritance of family property. Still, the majority (52\%) maintains that only boys should be inheritors of family property, while $10 \%$ have no answer.

\section{Conclusions}

Starting from the results of the research, we have come to these final findings:

The current practice regarding the inheritance of property by Albanian female heirs in Macedonia is contrary to the goal of positive legal norms and international law on gender equality, and as such it should be excluded.

Positive legal norms are insufficient to deal with traditional practices, so there is a need for more precise regulation. Thus, legal changes are needed to avoid deficiencies as a preventive measure against circumstances where women's legal rights may be violated. This requires a great deal of effort by the Government, respectively the Ministry of Justice, the courts and notaries to eliminate the omission of gender equality in inheritance issues.

Female heirs are pressured to renounce their rights through family expectations and tradition, while legislation covering the inheritance issue lacks protective measures for persons who are forced to resign from their inheritance right.

The exclusion of female heirs from inheritance affects their economic power and social status in society, while the inclusion of girls into inheritance would have empowered their role in the husband's family. 
In rural areas, the inclusion of female heirs in inheritance is lower than in urban areas, though urban female heirs are considered to be inherited in small percentages compared to male heirs in the family. Rural women are biased by tradition and living experience, as marginalized, economically dependent on the husband, uneducated and overburdened with housework, farming, and livestock.

There is a connection between the education level of girls and the realization of the right to inheritance since the educated daughter has more awareness and is more persistent in the right to inheritance.

With the emancipation of girls in contemporary families, the issue of inheritance remains more family and personal than traditional and stereotyped, while parents and brothers are beginning to correctly understand the issue of gender equality and inheritance in particular.

The inheritance situation shouldn't be understood as a war between the sexes, as today there are families who have a very moderate approach in respecting gender equality in inheritance, while the girls come out in substantial material support, housing, schooling, car, etc.

In conditions of contemporary democracy, the traditional patriarchal model is in the weakness due to the empowerment of women in politics, education, and institutions. Thus, families are not as patriarchal as in the past, and today women can be seen as deputies, ministers, mayors, directors, teachers, professors, doctors, lawyers, judges, and so on.

\section{Suggestions}

Legal amendments should emphasize that civil laws will prevail over customary laws and practices that discriminate against female heirs during the inheritance process.

Institutions at central and local government level with competences on gender equality should monitor the situation regarding inheritance, and propose measures to reduce the differences that occur in practice, but also develop campaigns to educate the population on the importance of gender equity in inheritance.

Civil judges and notaries, as competent persons in inheritance processes, should be trained and encouraged to respect full equality in the inheritance process in the spirit of the law.

New generations in the school should be educated about gender equality, including issues in the area of property rights. In this regard, specialized staff from the Ministry of Education and the Ministry of Justice should be engaged through specific programs to help overcome stereotypes in society in the younger generation community.

Civil Society Associations should be more active through projects in informing the population of legitimate inheritance rights, especially in rural areas. They should do: campaigns, meetings with citizens, and distribute leaflets and other educational materials, information and promotional brochures in all municipalities; raise public awareness through TV spots, electronic platform discussions. All this, to encourage and raise awareness among parents, for an equal access to property sharing between boys and girls.

Civil Society Associations for Women's Rights should be involved in the preparation of legal changes to inheritance. So the lawmaker should include in consultations and take into account their suggestions regarding future legal changes.

As a result of comparative experiences and socio-economic changes in Macedonia, the lawmaker should seriously consider entering into the legal system of the inheritance new elements such as: Heritage Contract, Notary Testament, Registry of Wills, and the principle of Universal Succession.

As a minimum safeguard measure that needs to improve the current situation, the competent court should hold a separate hearing with the heirs who express an interest in renouncing their inheritance rights by ensuring that they have been fully informed for their legal rights, the value of the hereditary estate, the location of the property. This rejection of interest should be done voluntarily, with legal representatives, through documents in a simple and understandable language.

In cases where there is no identified heir who wants to give up, heirs who have brought the case to the notary or judge should be required to swear that they aren't excluding any known heirs.

An issue that remains to be explored in the future may be: If the expression of the heir's resignation to the competent institution (notary) is voluntary or influenced by the above-mentioned circumstances, and how the notary can affect the fair 
expression the will of the resigning party? This is necessary since the statement of resignation (as evidence) is likely to be motivated by the aforementioned factors and as such, it shouldn't have this weight of the inheritance stage because it is given under pressure and against the will.

\section{Literature}

[1] Austrian General Civil Code / Allgemeines bürgerliches Gesetzbuch (ABGB) für die gesammten deutschen Erbländer der Oesterreichischen Monarchie, StF: JGS Nr. 946/1811

[2] Boman S. \& Krasniqi Nj. (2012), "The Kanun of Lekë Dukagjini..." Malmö University-Department of Global Political Studies

[3] CEDAW (2004), Consideration of Reports Submitted by States Parties under Article 18 of the Convention on the Elimination of All Forms of Discrimination against Women: FYROM, Combined Initial, Second and Third Reports of States Parties, CEDAW/C/MKD/1-3, New York

[4] Census of Population, Households and Dwellings in the Republic of Macedonia, THE STATE STATISTICAL OFFICE (SSO), 2002

[5] Civil Code of Czech Republic, 89/2012 Sb. ACT of 3 February 2012

[6] Code civil français, Dernière modification le 02 mars 2017 - Document généré le 11 septembre 2017

[7] Commission staff working document FYR of Macedonia 2009 progress report, Brussels, 14.10.2009

[8] Commission staff working document the FYR of Macedonia 2008 progress report, Brussels, 5.11.2008

[9] Commission staff working document the FYR of Macedonia 2010 progress report, Brussels, 9 November 2010

[10] Commission staff working document the FYR of Macedonia 2012 progress report, Brussels, 10.10 .2012

[11] Commission staff working document, The FYR of Macedonia 2015 Report, Brussels, 10.11.2015

[12] Commission staff working document, The FYR of Macedonia 2016 Report, Brussels, 9.11.2016

[13] Commission staff working paper the FYR of Macedonia 2011 progress report, Brussels, 12.10.2011

[14] Conclusions on the FYR of Macedonia (extract from the Communication from the Commission to the European Parliament and the Council 'Enlargement Strategy and Main Challenges 2013-2014', COM (2013)700 final

[15] Cvetanovska J. (2014), „Ulogata na ženata vo tradiciskata kultura“. In: Za etnologijata.., Skopje: IEA

[16] Eccher V.(2002), Bürgerliches Recht, VI, Erbrecht, Wien, p.71; in: Nataša Stojanović, „Zašto je ugovor o nasleđivanju zabranjen u našem pravu" Pravni život, br. 10/2003

[17] ERLICH, V., Porodica u transformaciji, Zagreb, 1964

[18] Frishchik, Jasminka and Duarte, Marianna (2007) 'Briefing for the Human Rights Committee from the Association for Emancipation, Solidarity and Equality of Women of the Republic of FYROM (ESE) in partnership with the World Organisation Against Torture (OMCT), Skopje

[19] Gajtanoska A.(2017), The daughter who gave up her inheritance: Ethnography of women's inheritance rights and their application in contemporary: Macedonian context, Institute of ethnology and anthropology, Skopje, Issues in Ethnology and Anthropology, Vol.12

[20] German Civil Code, in the version promulgated on 2 January 2002 (Federal Law Gazette [Bundesgesetzblatt] I page 42, 2909; 2003 I page 738), last amended by Article 4 para. 5 of the Act of 1 October 2013 (Federal Law Gazette I page 3719)

[21] Hrvatski zakon o nasljeđivanju / Croatian Heritage Law, Official Gazette No. 48/03 "Narodne novine", broj $48 / 03$

[22] International Bank for Reconstruction and Development / The World Bank (2011) Women, Business and the Law 2012: Removing Barriers to Economic Inclusion. Measuring gender parity in 141 economies, IBRD / World Bank, Washington DC

[23] Joireman, S.F.(2015), "Resigning Their Rights? Impediments to Women's Property Ownership in Kosovo", in: Global Trends in Land Tenure Reforms: Gender Impacts, edited by Caroline Archambault and Annelies Zoomers, Routledge

[24] Kaser, K. (2008) Patriarchy after Patriarchy, Gender Relations in Turkey and in the Balkans, 1500 - 2000. Studies on South East Europe

[25] Klarić P. \& Vedriš M.(2006), GRAĐANSKO PRAVO, Opći dio, stvarno pravo, obvezno i nasljedno pravo, X izdanje, Narodne Novine, Zagreb

[26] Louis Garb, International Succession, Kluwer Law International, 2004. 
[27] Memeti M.(2017), "Hulumtim mbi të drejtat pronësore dhe trashëgimore, Civica Mobilitas, Tetovë

[28] Mircevska M.P.(2008), The Status and Role of the Village Woman and Family Relations in the Republic of Macedonia (19th-20th Centuries) in: Social Behaviour and Family Strategies in the Balkans (16th-20th Centuries) Actes du colloque international 9-10, Juin 2006 New Europe College Bucarest

[29] Mitrevska T.C.(2017), "Land and Gender: Macedonian experience", Agency for Real Estate Cadastre, Republic of Macedonia, Paper presented at the "2017 WORLD BANK CONFERENCE ON LAND AND POVERTY", The World Bank-Washington DC

[30] Official Gazette of R Macedonia, no. 18 of March 5, 2001

[31] Official Gazette of RM no.66 / 06 dated 29.05.2006

[32] Official Gazette of the Republic of Macedonia, No. 153 from 20.10.2014

[33] Official Gazette of the Republic of Macedonia, No.47 dated 12.09.1996

[34] Pravni leksikon, Savremena administracija, Beograd, 1964

[35] Risteski, L.,(2002), "The Woman in Macedonian Folk Culture". Gender Relations in South Eastern Europe: Historical Perspectives on Womanhood and Manhood in 19th and 20th Century, Belgrade-Graz

[36] Ristov A., Дали е потребен договорот за наследување во македонското наследно право, Chambre des notaires de la République de Macédoine (HОTAPИУC), 19/2012, pp.70-82

[37] Roald A.S.(2001), "Women in Islam: the Western Experience", Routledge/London

[38] Social Institutions \& Gender Index Synthesis Report 2014, OECD

[39] Spanish Civil Code, Código Civil aprobado por Real Decreto de 24 de julio de 1889

[40] Stjepanović-Zaharijevski, D.(2006), Društveni položaj seoskih žena u fokusu jednog razvojnog projekta. Glasnik Etnografskog instituta SANU LIV

[41] Strategjia kombëtare për të drejtat pronësore në Kosovë, USAID \& Ministry of Justice of Kosovo, December 2016

[42] Svetieva A.(2002), "Female Seniority Principle and Accompanying Elements in the Traditional Culture of Macedonians". Gender Relations in South-Eastern Europe: Historical Perspectives on Womanhood and Manhood in 19th and 20th Century, Belgrade-Graz.

[43] Vangjeli A.(2010), Ефективни имотни и наследни права на жените во PM, in: "Кон родово рамноправна Македонија", CRPM, Skopje

[44] Закон за еднакви можности помеѓ жените и жените / Law on Equal Opportunities Between Man and Women, Official Gazette of RM no.66 / 06 dated 29.05.2006

[45] Закон за изменување и дополнување на Законот за облигационите односи / Law on Amending and Supplementing the Law on Obligatory Relations, „Службен весник на Република Македонија“ бр. 84/2008.

[46] Закон за наследство / inheritance law, Official Gazette of the Republic of Macedonia, No.47 dated 12.09.1996

[47] Закон за семејство / Family Law, Official Gazette of the Republic of Macedonia, No. 153 from 20.10.2014

[48] Закон за сопственост и други стварни права / Law on Property and Other Real Rights, Official Gazette of Macedonia, no.18, March 5, 2001

[49] Закон о наслеђивању у Републици Српској / Law on Inheritance in the Republic of Srpska,"Службени гласник" $1 / 2009$.

[50] Закон о наслеђивању Црне Горе / The Law on Inheritance of Montenegro, "Službeni list Crne Gore, broj $74 / 2008$ " od 5.12.2008

[51] Законот за вонпранична постапка / Non-litigation Procedure, „Службен весник на Република Македонија“ бр. 9/2008.

[52] Законот за вонпранична постапка „Службен весник на Република Македонија“ бр. 9/2008. 